\title{
RISK SOCIETY IN HOUSING: RESPONSIBILIZATION AND THE SOCIALIZATION OF RISK
}

\author{
Vera Csilla Horváth ${ }^{l}$
}

The concept 'risk society', a term coined by German sociologist Ulrich Beck, was discussed in depth both by Beck himself and English sociologist Anthony Giddens. Both authors use the term to theorize modern societies in the context of intensifying globalisation, where the most relevant risks to members of a modern society are 'manufactured' (man-made) rather than naturally occurring. While Giddens maintained that society's class structure moderates these risks, Beck's work remained more closely centred on the concept of risk society itself, complete with a rich terminology of related phenomena, and the claim that 'risk society' will eventually transform 'class society'. ${ }^{2}$ Beck's writings proved inspiring to researchers, but also attracted criticism. In the context of the Global Financial Crisis (GFC) and the subsequent 'Great Recession' after 2008, a number of researchers who addressed the housing and household-related finance consequences of the crisis also incorporated the notion of the risk society and some of the related concepts into their analysis. This was inspired not only by Beck's (and Giddens') works, but also by the realization that households have come to bear a far greater share of the risks of financing housing than in previous major economic downturns due to the long-standing, gradual 'socialization' of these risks. These accounts suggest a public policy discourse in which risks are presumed to be evenly or 'fairly' distributed among social actors; however, in real life outcomes they prove to more significantly affect lower income and vulnerable social strata. In this sense, risk society does not replace class society - instead, the distribution of risks reinforces or even exacerbates class divisions.

1 Vera Csilla Horvath is a Ph.D. student at the Doctoral School of Sociology, Corvinus University of Budapest; e-mail: vera.horvath@mri.hu

2 Beck, Ulrich 1992, Risk Society: Towards a New Modernity. London: SAGE. More recent writings that add to and refine the concept of 'risk society' and elaborate its terminology include World at Risk (Cambridge: Polity Press 2009); and 'Why "class" is too soft a category to capture the explosiveness of social inequality at the beginning of the 21st century' (British Journal of Sociology, 64(1), 63-74, 2013). 
Rather than reviewing a single volume, this review paper sets out to explore the (so far limited) literature on the scalar and sectoral shift of 'manufactured risk' associated with financing housing production and housing provision from central governments and financing institutions to increasingly lower levels of government, third-party actors and private households through a process of 'socialization' of risks, 'responsibilization' of households, and 'organised irresponsibility'. While the articles described here are diverse in focus, they all discuss phenomena related to the evolution of housing affordability, household indebtedness, and a shift from housing provision in the framework of the welfare state to not only the privatisation and marketization of housing, but also an overall shift from housing finance-related risks from central state bodies and financing institutions to private households.

Although the term 'risk society' is connected to both Giddens and Beck in relation to social phenomena brought about by recent intensifying globalisation, Beck's work focuses more closely on centring the understanding of modernity on the notion of risks brought about by human action; he has also produced a rich set of terms useful in analysing a range of social processes, even outside his intended fields of analysis. Beck argued that in traditional societies risks were largely limited to natural hazards, whereas in modern society economic and technological development has led not only to growth in wealth through the increase in the production and distribution of goods, but as a systemic side effect it also entails the 'social production of risk's. The types of risk most relevant to human society, he argues, are man-made, like climate change, financial crises, or nuclear threats; and in a system of organised irresponsibility, a major risk event typically cannot be traced to a single accountable person. Beck postulated that 'risk society' would replace 'class society', as major risk events affect people regardless of their social standing. ${ }^{4}$ He later came to acknowledge a geographic gradation of risk, distinguishing 'risk donor countries' and 'risk recipient countries'; $;$ but continued to emphasize the incalculability of risk and its consequent transcendence of class divides. More recently he exemplified major risk events: 'Chernobyl, 9/11, climate change, the financial crisis, Fukushima, the euro crisis' ${ }^{\text {', }}$ but maintained that 'risk logic' is fundamentally different from 'class logic'.

A fair share of criticism of Beck's assumption that social class loses its significance in relation to risk has pointed to the role of class position in

3 Beck 1992:19

4 Beck 1992:227.

5 Beck 2009:30.

6 Beck 2013:64

CORVINUS JOURNAL OF SOCIOLOGY AND SOCIAL POLICY VOL. 8 (2017) 2 
mitigating risks, including man-made ones. Sociologist Dean Curran went a step further and highlighted the ways in which the social production of risks may in fact increase the relevance of class. ${ }^{7}$ In a 2013 article, Curran gives a detailed overview of the main arguments against Beck's claims that class distribution will be replaced by risk distribution by repeatedly demonstrating that class remains relevant to structuring the distribution of wealth, and through it, life chances. ${ }^{8}$ He then goes on to diametrically oppose Beck's view on risk and class, stating that the theory of risk society "contains the basis of a critical theory of class relations of risk society', ${ }^{9}$ which reinforces rather than fundamentally transforms the logic of social distribution, even in the context of increasing man-made risk. According to Curran, risks are not only gradable within a single society, but their stratification follows class lines. Even in the case of maximum risks that threatens all life in a region or even on Earth (like a nuclear disaster or environmental pollution), only the initial distribution of risk is independent of class. After a disaster event with lasting consequences, people with adequate means will move to the least affected areas, while those with limited resources continue to occupy the exposed spaces; risk positions will therefore be structured by class positions. Curran not only claims that class structure reflects wealth distribution, which in turn continues to have clear relevance to life chances - in fact, 'in the risk society, inequalities in themselves become the means of exacerbating exposure to hazard and risk'. ${ }^{10}$

In a more recent article ${ }^{11}$ Curran further develops his framework using Beck's terminology to conceptualize inequality in differing risk positions in the events leading up to the $2008 \mathrm{GFC}$ and subsequent recession, giving an account of 'the social production and distribution of systemic financial risk in a context of organized irresponsibility'. ${ }^{12}$ While in his 2013 study Curran pointed out that major risk events not only replace or reproduce but actually deepen existing unequal class positions, in this article he takes a look at whether the same relationship between risk position and class position holds true for systemic financial risk. In the economic and housing market boom preceding the crisis, economic actors in key positions deployed a number of increasingly complex and innovative financial

\footnotetext{
7 Dean Curran 2013, 'Risk society and the distribution of bads: theorizing class in the risk society.' The British Journal of Sociology 64(1) pp. 44-62.

8 Curran 2013:45-46.

9 Curran 2013:46.

10 Curran 2013:53.

11 Dean Curran 2015, 'Risk illusion and organized irresponsibility in contemporary finance: rethinking class and risk society.' Economy and Society 44(3) pp. 392-417.

12 Curran 2015:392.
} 
products, with the help of which they not only produced risk and value (and increased their profit and bonuses), but were also able to avoid the consequences of failed high-risk ventures, producing a clear case of organised irresponsibility. While some people gained excessively from heightened risk production, these were not the same people who were left to suffer the consequences when the ventures failed. ${ }^{13}$ In the decades preceding the crisis, banks gradually transformed from cautiously behaving partnerships to increasingly more risk-taking and profitable publicly traded companies, in which owners and senior bankers diverged, and the new commercial banking system 'socially instituted a particularly extreme relation of organized irresponsibility, in which senior bankers could benefit from the risks they created without bearing the consequences of these risks'. ${ }^{14}$ By the 2000s, financing institutions were applying increasingly risky strategies to maximise gain. Innovative financial products had already been around for decades, but by the early to mid-2000s large-scale and complex instruments had been developed to shield senior bankers from financial risk, the brunt of which was shifted to investors, ranging from professional institutions to private borrowers and mortgagors. High-risk banking was not the single cause of the GFC, but it did contribute to the production of systemic financial risk, while incremental innovation in retail loan products spread this risk over huge segments of society. In conclusion, Curran reiterates that 'the social production and distribution of risk in a context of organized irresponsibility' in the years leading up to the GFC and during its unfolding was not only strongly affected by class relations, but with all its outcomes and consequences considered, it in fact contributed to deepening class divides.

The 2016 edited volume Risking Capitalism specifically examines risk-shifting among housing market actors, inspired by insights similar to Curran's: while the socialization of housing finance-related risk was a gradual process lasting decades, the GFC indicated that the amount of financial risk shifted from largescale professional actors to private individuals would inevitably have severe social consequences. While the increasing wealth produced through innovation in housing finance benefitted wide segments of society who aspired to become home owners, the brunt of the associated risks was shifted to borrowers on the one hand, and the public sector on the other. Two articles in particular treat the issue of housing and the socialization of housing finance-related risks, departing from a multi-decade overview of the risk-shifting process from both the private sector and central governments to private households and lower levels

13 Curran 2015:394-396.

14 Curran 2015:405.

CORVINUS JOURNAL OF SOCIOLOGY AND SOCIAL POLICY VOL. 8 (2017) 2 
of governance. ${ }^{15}$ While these articles do not explicitly address the connection between risk exposure and class position, both point to the more vulnerable position of lower-income social groups in a context where mainstream political communication seems to imply an even or 'fair' distribution of risks.

Adrianne Roberts examines the consequences of the GFC on the UK housing and food crisis, particularly its long-term effects on low-income segments of society and persons at risk of homelessness, with two primary foci: financialization, and the privatization of social reproduction. ${ }^{16}$ After theorizing the concept of financialization, social reproduction, and the financialization of social reproduction through household indebtedness in the framework of feminist political economy, Roberts sets out to discuss housing related risks and debt, and the development of welfare provision leading up to the post-GFC food crisis. With regard to housing risk, she provides an account of the deregulation and marketization measures of housing finance in previous decades. Mortgage markets were liberalized since the 1980s, and financial institutions were able to pass much of their budgetary risk to investors including small scale investors - through securitization instruments. In the same period, much of public task housing was privatized, and central housing subsidies were heavily cut. These measures stimulated private investment in housing by investors and private households; but they also deepened the financialization of the housing sector, and the depletion of public task housing. Private households accumulating debt to secure their housing became the social norm, a strategy which is particularly risky for low-income families; and this was accompanied by the individualization and marketization measures through which 'the risks of the financial sector were socialized', ${ }^{17}$ that is, associated risks were increasingly shifted to private households. After the GFC, the adverse consequences of the risks taken by the financial sector were further socialized through bailout mechanisms. In the end, Roberts concludes, while the British economy seems to have begun to recover after the crisis, the financialization of social reproduction continues as if the recovery had never happened. The working class, the poor, and single-parent households in particular absorb much of the risk - and the cost - of widespread household indebtedness and post-crisis tax and benefit restructuring.

15 Susanne Soederberg (ed.) 2016, Risking Capitalism, Research in Political Economy, Volume 31, Emerald Group Publishing.

16 Adrianne Roberts 2016, 'Household Debt and the Financialization of Social Reproduction' in Susanne Soederberg (ed.) Risking Capitalism (pp. 135-164).

17 Roberts 2016:144. 
In the same volume, Walk and Simone ${ }^{18}$ present the case of Canada's housing sector, looking at the relationship between 'neoliberalisation', financialization, and the evolution of risk management. They present the way financialization shifted risk not only among sectors but also among different scales of government and institutions, from the federal state to lower levels of government, third-sector organisations, and private households. The authors seek to understand the changes in risk associated with the Canadian housing sector through housing finance and policy development, basing their analysis on the concept of risk society alongside financialization, and point out the importance of organized irresponsibility. In an overview of Canadian housing policy, the authors describe changes in the loci and bearers of risks associated with financing housing since World War II, from the Fordist-Keynesian postwar decades to the 'privatized Keynesian' approach of incentivizing private households to stimulate the economy through taking on increasing debts, and then to the 'neoliberalisation' period starting in the mid-1980s, when marketbased mechanisms were introduced into public housing provision to improve efficiency. ${ }^{19}$ By the late 1990s, housing-related spending by the state was almost entirely reduced to mortgage insurance. At the same time, the responsibility to provide affordable housing was shifted further down to local providers and municipalities with limited financial leverage in times of crisis or recession. ${ }^{20}$ Walker and Simone note that while the risks of household indebtedness are fairly well understood by policy makers, many federal politicians continue to argue for more access to credit for low-income households. By 2015, they write, 'each individual household fully bears their own risk of default' with the federal state only retaining the responsibility for mortgage insurance - insuring the lender, not the borrower. ${ }^{21}$ To illustrate the social risks this situation entails, the authors close the main text of the article with a quote from Bank of Canada governor Steven Poloz: 'Borrowers and lenders ... bear the ultimate responsibility for their own decisions at the individual and firm level. It is not the role of monetary policy to protect individuals from making bad choices.'

This process of risk shifting towards private individuals, referred to as 'responsibilization', is also a central theme of Stonehouse and colleagues, who present the case of low-income households facing housing risk in the post-

18 Alan Walks - Dylan Simone 2016, 'Neoliberalization through Housing Finance, the Displacement of Risk, and Canadian Housing Policy: Challenging Minsky's Financial Instability Hypothesis' in Susanne Soederberg (ed.) Risking Capitalism (pp.49-77).

19 Walker and Simone 2016:57-63.

20 Walker and Simone 2016:65-66.

21 Walker and Simone 2016:69.

CORVINUS JOURNAL OF SOCIOLOGY AND SOCIAL POLICY VOL. 8 (2017) 2 
GFC context in Victoria, Australia. ${ }^{22}$ This analysis emphasizes the process of responsibilization within the neoliberal political discourse, showing how political discourse underpins the shifting of systemic risk from public bodies and financing institutions to private households. This process is typically played out through invoking the concept of 'self-reliance', 'fiscal responsibility' and the threat of 'welfare dependency' in fields ranging from unemployment to poverty, health, education, and homelessness. ${ }^{23} \mathrm{~A}$ 'pathway to independence' is expected of the subsidized population, which, in the case of housing, would entail a 'transition into the private market' through cutting off the 'disincentive' of public funding. In the authors' view, however, housing risk is socially constructed and unequally distributed due to economic and social stratification. In their assessment, the risks of a market-based housing solution - whether debtbased ownership or private rented housing - are far from diminishing, and the private sector has repeatedly demonstrated its inability to provide affordable and adequate housing to vulnerable populations.

In conclusion, the concept of risk society and the associated terminology developed in Beck's writing is useful for describing the social and economic processes affecting households at times when a major 'manufactured' risk event occurs. In the cited cases, the focal financial risk event was the Global Financial Crisis: its consequences reveal that numerous households had been shouldering much more risk than they could afford due to incremental regulatory and mortgage market changes over the previous decades. The crisis affected all social strata in most developed countries, with harsh consequences even for affluent middle classes; and in this sense it did correspond to Beck's notion of a major risk event. However, its adverse effects were far from equally distributed; in the examined cases, they did follow class lines (a major source of risk in this case stemmed from the higher likelihood of those with a lower income taking on loans with very low or no own contribution, or opting for a higher-risk mortgage product with a lower initial cost). Whether Curran's assessment is correct that major risk events further widen inequalities may depend on country-specific factors as well. Nonetheless, the events of the GFC do seem to suggest that while the concept of risk society may be a useful analytical tool for understanding certain phenomena in modern societies, it is unlikely to bring about the end of class divisions.

22 Stonehouse, Darran - Guinever Threlkeld - Jane Farmer 2015. 'Housing risk' and the neoliberal discourse of responsibilisation in Victoria. Critical Social Policy 35(3) pp. 393-413.

23 Stonehouse et al. 2015:396

CORVINUS JOURNAL OF SOCIOLOGY AND SOCIAL POLICY VOL. 8 (2017) 2 
